\title{
Contextual Effect of Integrated Health Post, Socioeconomic and Physical and Mental Health Determinants on the Quality of Life among Elderly in Klaten, Central Java
}

\author{
Annisa Nur Fauziyah'), RB. Soemanto²), Rita Benya Adriani3) \\ 1)Masters Program in Public Health, Universitas Sebelas Maret \\ 2)Faculty of Social and Political Sciences, Universitas Sebelas Maret \\ 3)School of Health Polytechnics, Ministry of Health, Surakarta
}

\section{ABSTRACT}

Background: The increase in life expectancy has an impact on the number of elderly which has increased from 9.3\% (2018) to $15.8 \%$ (2035). Decreased body function in the elderly disturbs health and inhibits activities so that quality of life decreases. The purpose of this study was to analyze the contextual effect of Elderly Integrated Health Post, socioeconomic determinant, physical and psychological health on the quality of life of the elderly.

Subjects and Method: The design of the study was cross sectional. This study was conducted in Klaten, Central Java, from August to September 2019. A sample of 200 elderly people aged $\geq 60$ years was selected by simple random sampling. The dependent variable was the quality of life of the elderly. The dependent variables were marital status, employment status, income, eating pattern, physical activity, nap, sexual activity, and activeness to participate in Integrated Health Post. The data was obtained by using questionnaires. Eating patterns were measured by DDS questionnaire. Physical activity data were measured by PASE. Data on quality of life of the elderly were measured using WHOQOL-OLD. The data were analyzed by multilevel.

Results: The quality of life in elderly improved with marriage $(b=4.94 ; 95 \% \mathrm{CI}=2.49$ to 7.34 ; $\mathrm{p}<0.001)$, working $(\mathrm{b}=6.47 ; 95 \% \mathrm{CI}=3.18$ to
9.76; $\mathrm{p}<0.001)$, high income $(\mathrm{b}=3.91 ; 95 \% \mathrm{CI}=$ 1.45 to $6.37 ; \mathrm{p}=0.002)$, good eating pattern $(\mathrm{b}=$ 2.08; $95 \% \mathrm{CI}=0.14$ to $4.02 ; \mathrm{p}=0.036)$, high physical activity $(\mathrm{b}=3.87 ; 95 \% \mathrm{CI}=0.80$ to 6.93 ; $\mathrm{p}=0.013)$, adequate nap time $(\mathrm{b}=6.29 ; 95 \% \mathrm{CI}=$ 3.05 to 9.55; $\mathrm{p}<0.001)$, active sexual activity $(\mathrm{b}=$ 2.97; $95 \% \mathrm{CI}=0.93$ to $5.02 ; \mathrm{p}=0.004)$, and often attend integrated health post $(b=2.18 ; 95 \% \mathrm{CI}=$ 0.28 to $4.09 ; p=0.025)$. Elderly integrated health post had a contextual effect on the quality of life of the elderly with ICC $=45.65 \%$.

Conclusion: The quality of life in elderly improves with marriage, working, high income, good eating pattern, high physical activity, adequate nap time, active sexual activity, and often attend integrated health post. Elderly integrated health post has a contextual effect on the quality of life of the elderly.

Keywords: quality of life, elderly, integrated health post

\section{Correspondence:}

Annisa Nur Fauziyah. Masters Program in Public Health, Universitas Sebelas Maret. Jl. Ir. Sutami 36A, Surakarta 57126, Central Java. Email: annisafauziyaho3@gmail.com. Mobile: +6282335197211.

Cite this as:

Fauziyah AN, Soemanto RB, Adriani RB (2020). Contextual Effect of Integrated Health Post, Socioeconomic and Physical and Mental Health Determinants on the Quality of Life among Elderly in Klaten, Central Java. J Epidemiol Public Healt. 5(1): 15-25. https://doi.org/10.26911/jepublichealth.2020.05.01.02

cc (i) (2) Journal of Epidemiology and Public Health is licensed under a Creative Commons Attribution-NonCommercial-ShareAlike 4.0 International License.

\section{BACKGROUND}

The success of a country's development is shown through several indicators one of them in the health sector, namely the in- crease in Life Expectancy (UHH) which reflects the higher quality of life (Ministry of Health, Republic of Indonesia, 2014). 
Fauziyah et al./ Contextual effect of integrated health post, socioeconomic

Increased Life Expectancy (UHH) causes the percentage of the elderly population to continue to increase from $9.3 \%$ in 2018 and is predicted to reach $15.8 \%$ in 2035 (Ministry of Health Republic of Indonesia, 2010; IBRA, 2013).

Indonesia experienced an increase in Life Expectancy in 2010 by 69.8 years to 70.9 years in 2017 (Statistics, 2017). Life expectancy (of Central Java Province in 2017 is 76.02 years (Department of Health of Central Java Province, 2018). Klaten Regency was ranked 7 th with the highest life expectancy in Central Java Province in 2017 at 76.62 years (Health Office of Klaten Regency, 2018; Statistics, 2017).

An elderly person was someone who has reached the age of 60 years and over $(\geq$ 60 years). The number of elderly in Indonesia is 23.4 million in 2017. The elderly in Central Java Province reach 4.31 million (Central Java Provincial Health Office, 2018). Elderly in Klaten is classified as quite high, namely 188, 141 inhabitants (Klaten District Health Office, 2018).

The following is an illustration of the elderly in Indonesia today: the high number of elderly living with their partners is $59.82 \%$, as many as $47.92 \%$ of the elderly are still productive in working even though their income level is relatively low (Statistics, 2017). Daily eating patterns tend to vary less (Bahrami et al, 2016). The elderly tend to live a sedentary lifestyle (Lewa, 2016). Sleep patterns change (Miner and Kryger, 2018). Sexual activity also decreases (Ropei, 2013). Changes that occur in the elderly cause various complaints and health problems that hamper daily activities, so that the quality of life decreases (Rusli, 2012).

U.S. Data News and World Report (2018) mention Canada to be the country with the best quality of life in the world. Indonesia is ranked 34th. Based on these data, the quality of life of the elderly in Indo- nesia is still relatively low so there needs an immediate improvement. Efforts to improve the quality of life need to be carried out comprehensively and continuously. One of them is through the activities of the Elderly Integrated Health Post (Indonesian Ministry of Health, 2010).

A similar study was carried out by Swastika et al. (2017), entitled Biopsychosocial Determinants of Quality of Life in the Elderly at Tresna Werdha Social Nursing Home, Yogyakarta. The study shows that health status, level of independence, intellectual function, depressive status, and social activity are determinants of the quality of life of the elderly. Things which distinguish from this study include the variables studied, the location of the study, and the technique of taking subjects of the study.

Based on the background above, the researchers wanted to conduct a study entitled "Multilevel analysis of the contextual effect of integrated health post, socioeconomic and physical and mental health determinants on the quality of life among elderly in Klaten, Central Java".

\section{SUBJECTS AND METHOD \\ 1. Study Design}

This was a cross sectional study conducted in Klaten, from August to September 2019. The study was conducted in 25 elderly integrated health posts in Ceper, Jambu Kulon, and North Klaten health centers, in Klaten, Central Java.

\section{Population and Sample}

The source population was the elderly who were aged $\geq 60$ years in Klaten community health center, Central Java, from August to September 2019. A sample of 200 elderly was selected by random sampling.

\section{Study Variables}

The dependent variable was the quality of life of the elderly. Independent variables were marital status, employment status, income, 
Fauziyah et al./ Contextual effect of integrated health post, socioeconomic

eating patterns, physical activity, nap, sexual activity and activeness to participate in integrated health post.

\section{Operational Definition of Variables}

Marital status was the status of an inner and outer bond between a man and a woman legally approved as husband and wife.

Job status was activities carried out by subjects of the study in order to earn income. Income was all results received by study subjects within a certain period obtained from work, business or gifts from the family and are used to meet daily needs.

Eating pattern was variations in the types of food consumed by study subjects in one day.

Physical activity was body movements that require energy needed by subjects of the study to do various daily activities.

Nap was the quality and quantity of subjects of the study using their time off napping.

Sexual activity was the quality and quantity of study subjects and their partners in carrying out activities related to sexual activity (marital relations).

\section{Participation in Integrated Health Post} was quality and quantity of study subjects in participating in the Elderly Integrated Post from January to August 2019.

Quality of life was perceptions of study subjects regarding their ability to carry out daily activities in accordance with their health conditions.

\section{Study Instruments}

Data collection in this study used a study instrument in the form of questionnaires. Eating pattern data were measured using Dietary Diversity Score. Physical activity data were measured using the Physical Activity Scale for Elderly.

Data on quality of life of the elderly were measured using the World Health Organization Quality of Life - OLD. Other variable data were measured using question- naires from other studies that have been developed by researchers.

\section{Data Analysis}

Univariate analysis was aimed to explain the general picture of data of the study on each study variable. Bivariate analysis was aimed to explain the correlation of one in-dependent variable to one dependent variable using chi-square. Multivariate analysis was aimed to explain the effect of more than one independent variable, using the multiple logistic regression method with a multilevel analysis model characterized by Intra Class Correlation (ICC) values.

\section{Research Ethics}

The ethical aspects of this study consisted of informed consent, anonymity, confidentiality and ethical clearance. Ethical clearance was obtained from Dr. General Hospital Moewardi, Surakarta, Central Java, with the number: 996/VIII/HREC/ 2019.

\section{RESULTS}

\section{Sample Characteristics}

The subjects in this study were the elderly aged $\geq 60$ years. The distribution of characteristics of study subjects is shown through table 1.

\section{Univariate analysis}

Table 2 shows the results of the univariate analysis. Table 2 shows that most of the study subjects were still married (51.5\%), not working as many as 113 people (56.5\%), had high incomes as many as 111 people (55.5\%), had good eating patterns as many as 141 people (70.5\% ), had low physical activity as many as 116 people (58\%), had a nap as many as 126 people (63\%), did not actively engage in sexual activity with their partners as many as 122 people (61\%), often attended Integrated Health Post as many as 135 people $(67.5 \%)$ and had a good quality of life of 113 people (56.5\%). 
Fauziyah et al./ Contextual effect of integrated health post, socioeconomic

Table 1. Sample characteristics

\begin{tabular}{llcc}
\hline \multicolumn{1}{c}{ Characteristics } & \multicolumn{1}{c}{ Category } & n & \% \\
\hline Sex & Female & 149 & 74.5 \\
Age group & Male & 51 & $25 \cdot 5$ \\
& 60 -74 years & 155 & 77.5 \\
Recent education & $\geq 75$ years & 45 & 22.5 \\
& Low (<Senior High School) & 176 & 88 \\
Living Status & High ( $\geq$ Senior High School) & 24 & 12 \\
\multirow{2}{*}{ Living environment } & Alone/with spouse & 113 & 56.5 \\
& With children & 87 & 43.5 \\
& Rural & 136 & 68 \\
& Urban & 64 & 32 \\
\hline
\end{tabular}

Table 2. Univariate analysis

\begin{tabular}{|c|c|c|c|}
\hline Characteristics & Category & $\mathbf{n}$ & \% \\
\hline \multirow[t]{2}{*}{ Marital status } & Single & 97 & 48.5 \\
\hline & Married & 103 & 51.5 \\
\hline \multirow[t]{2}{*}{ Employment status } & No & 113 & 56.5 \\
\hline & Yes & 87 & 43.5 \\
\hline \multirow[t]{2}{*}{ Income } & Low $(<\operatorname{Rp} 1,795,061)$ & 89 & 44.5 \\
\hline & $\operatorname{High}(\geq \operatorname{Rp} 1,795,061)$ & 111 & $55 \cdot 5$ \\
\hline \multirow[t]{2}{*}{ Eating patterns } & Poor $($ score $<5)$ & 59 & 29.5 \\
\hline & Good (score $\geq 5$ ) & 141 & 70.5 \\
\hline \multirow[t]{2}{*}{ Physical Activity } & Low (score <117) & 116 & 58 \\
\hline & High (score $\geq 117$ ) & 84 & 42 \\
\hline \multirow[t]{2}{*}{ Nap } & No & 74 & 37 \\
\hline & Yes & 126 & 63 \\
\hline \multirow[t]{2}{*}{ Sexual Activity } & No & 122 & 61 \\
\hline & Yes & 78 & 39 \\
\hline Activeness in Following & Rarely ( $<4$ times in the last 8 months) & 65 & 32.5 \\
\hline Integrated Health Post & Frequent ( $\geq 4$ times in the last 8 months) & 135 & 67.5 \\
\hline \multirow[t]{2}{*}{ Quality of life } & Poor $($ score $<76)$ & 87 & 43.5 \\
\hline & Good (score $\geq 76$ ) & 113 & 56.5 \\
\hline
\end{tabular}

\section{The result of bivariate analysis}

Table 3 shows the results of the bivariate analysis. Table 3 shows that married (OR= 30.27; $95 \% \mathrm{CI}=13.73$ to $66.71 ; \mathrm{p}<0.001)$, working $(\mathrm{OR}=5.41 ; 95 \% \mathrm{CI}=2.87$ to 10.18 ; $\mathrm{p}<0.001)$, high income $(\mathrm{OR}=15.68 ; 95 \% \mathrm{CI}=$ 7.82 to $31.42 ; \mathrm{p}<0.001)$, good eating pattern $(\mathrm{OR}=2.76 ; 95 \% \mathrm{CI}=1.48$ to $5.17 ; \mathrm{p}=0.001)$, high physical activity $(\mathrm{OR}=4.85 ; 95 \% \mathrm{CI}=$ 2.58 to $9.11 ; \mathrm{p}<0.001)$, nap (OR=1.81; 95\% $\mathrm{CI}=1.01$ to $3.24 ; \mathrm{p}=0.044)$, active sexual activity ( $\mathrm{OR}=39.37 ; 95 \% \mathrm{CI}=13.43$ to 115.44 ; $\mathrm{p}<0.001$ ), and frequent in attending Integrated Health Post $(\mathrm{OR}=2.25 ; 95 \% \mathrm{CI}=1.23$ to $4.10 ; p=0.008$ ) improved quality of life of the elderly. 
Fauziyah et al./ Contextual effect of integrated health post, socioeconomic

Table 3. Bivariate analysis on the effects of socio-economic determinants, physical and psychological health on the quality of life of the elderly

\begin{tabular}{|c|c|c|c|c|c|c|c|}
\hline \multirow{3}{*}{ Variable } & \multicolumn{4}{|c|}{$\begin{array}{c}\text { The Quality of Life of the } \\
\text { Elderly }\end{array}$} & \multirow{3}{*}{ OR } & \multirow{3}{*}{$95 \% \mathrm{CI}$} & \multirow{3}{*}{$\mathbf{p}$} \\
\hline & \multicolumn{2}{|c|}{ Low } & \multicolumn{2}{|c|}{ High } & & & \\
\hline & $\mathbf{n}$ & $\%$ & $\mathbf{n}$ & $\%$ & & & \\
\hline \multicolumn{8}{|l|}{ Marital status } \\
\hline Single & 76 & 78.4 & 21 & 21.6 & 30.27 & $13.73-66.71$ & $<0.001$ \\
\hline Married & 11 & 10.7 & 92 & 89.3 & & & \\
\hline \multicolumn{8}{|l|}{ Employment status } \\
\hline No & 68 & 60.2 & 45 & 39.8 & 5.41 & $2.87-10.18$ & $<0.001$ \\
\hline Yes & 19 & 21.8 & 68 & 78.2 & & & \\
\hline \multicolumn{8}{|l|}{ Income } \\
\hline Low $(<\operatorname{Rp} 1,795,061)$ & 68 & 76.4 & 21 & 23.6 & 15.68 & $7.82-31.42$ & $<0.001$ \\
\hline High $(\geq \operatorname{Rp} 1,795,061)$ & 19 & 17.1 & 92 & 82.9 & & & \\
\hline \multicolumn{8}{|l|}{ Eating pattern } \\
\hline Bad score $<5$ & 36 & 61 & 23 & 39 & 2.76 & $1.48-5.17$ & 0.001 \\
\hline Good score $\geq 5$ & 51 & 36.2 & 90 & 63.8 & & & \\
\hline \multicolumn{8}{|l|}{ Physical Activity } \\
\hline Low score <117 & 68 & 58.6 & 48 & 41.4 & 4.85 & $2.58-9.11$ & $<0.001$ \\
\hline High score $\geq 117$ & 19 & 22.6 & 65 & 77.4 & & & \\
\hline \multicolumn{8}{|l|}{ Nap } \\
\hline Not & 39 & 52.7 & 35 & $47 \cdot 3$ & 1.81 & $1.01-3.24$ & 0.044 \\
\hline Yes & 48 & 38 & 78 & 62 & & & \\
\hline \multicolumn{8}{|l|}{ Sexual Activity } \\
\hline Not active & 83 & 68 & 39 & 32 & 39.37 & $13.43^{-}$ & $<0.001$ \\
\hline Active & 4 & 5.1 & 74 & 94.9 & & 115.44 & \\
\hline \multicolumn{8}{|c|}{ Attend Integrated Health } \\
\hline Post & 37 & 56.9 & 28 & 43.1 & 2.25 & $1.23-4.10$ & 0.008 \\
\hline Rarely $<4$ times & 50 & 37 & 85 & 63 & & & \\
\hline Often $\geq 4$ times & & & & & & & \\
\hline
\end{tabular}

\section{Multivariate Analysis}

Table 4 shows the results of multivariate analysis. Table 4 shows that married $(b=4.94$; $95 \% \mathrm{CI}=2.49$ to $7.34 ; \mathrm{p}<0.001)$, working $(\mathrm{b}=$ 6.47; 95\% CI $=3.18$ to $9.76 ; \mathrm{p}<0.001)$, high income $(\mathrm{b}=3.91 ; 95 \% \mathrm{CI}=1.45$ to $6.37 ; \mathrm{p}=$ o.002), good eating pattern $(b=2.08 ; 95 \%$ $\mathrm{CI}=0.14$ to $4.02 ; \mathrm{p}=0.036)$, high physical activity $(\mathrm{b}=3.87 ; 95 \% \mathrm{CI}=0.80$ to $6.93 ; \mathrm{p}=$ o.013), nap ( $b=6.29 ; 95 \% \mathrm{CI}=3.05$ to 9.55 ; $\mathrm{p}<0.001)$, active in sexual activity $(\mathrm{b}=2.97$;
95\% CI $=0.93$ to $5.02 ; \mathrm{p}=0.004$ ), and frequent in attending integrated health post $(\mathrm{b}=$ 2.18; $95 \% \mathrm{CI}=0.28$ to $4.09 ; \mathrm{p}=0.025$ ) had positive effect on the quality of life of the elderly.

Elderly integrated health post has strong contextual effect on the quality of life of the elderly with ICC $=45.65 \%$. This means that as much as $45.65 \%$ of the variation in the quality of life of the elderly is determined at the level of elderly integrated health post 
Fauziyah et al./ Contextual effect of integrated health post, socioeconomic

Table 4. Multilevel analysis on the effects of socio-economic determinants, physical and psychological health on the quality of life of the elderly

\begin{tabular}{|c|c|c|c|c|}
\hline \multirow{2}{*}{ Independent variables } & \multirow{2}{*}{$\begin{array}{c}\text { Regression } \\
\text { Coefficient (b) }\end{array}$} & \multicolumn{2}{|c|}{$95 \%$ CI } & \multirow[t]{2}{*}{$\mathbf{p}$} \\
\hline & & Lower limit & Upper limit & \\
\hline \multicolumn{5}{|l|}{ Fixed Effect } \\
\hline Having a partner (Married) & 4.94 & 2.49 & $7 \cdot 39$ & $<0.001$ \\
\hline Work (Yes) & 6.47 & 3.18 & 9.76 & $<0.001$ \\
\hline Income (High) & 3.91 & 1.45 & 6.37 & 0.002 \\
\hline Eating pattern (Good) & 2.08 & 0.14 & 4.02 & 0.036 \\
\hline Physical Activity (High) & 3.87 & 0.80 & 6.93 & 0.013 \\
\hline Nap (Yes) & 6.29 & 3.05 & 9.55 & $<0.001$ \\
\hline Sexual activity (active) & 2.97 & 0.93 & 5.02 & 0.004 \\
\hline Active to Integrated Health Post & 2.18 & 0.28 & 4.09 & 0.025 \\
\hline \multirow{2}{*}{\multicolumn{5}{|c|}{ Random Effect }} \\
\hline & & & & \\
\hline \multicolumn{5}{|l|}{ Integrated Health Post } \\
\hline $\operatorname{Var}($ constant) & 2.76 & 0.26 & 29.68 & \\
\hline $\mathrm{N}$ observation $=200$ & & & & \\
\hline LR test vs. Logistic Regression $=9.73$ & & & & \\
\hline $\mathrm{p}=0.009$ & & & & \\
\hline Interclass Correlation $(\mathrm{ICC})=45.65 \%$ & & & & \\
\hline
\end{tabular}

\section{DISCUSSION}

1. The effect of marital status on quality of life of the elderly

Marital status had a positive effect on the quality of life of the elderly and was statistically significant. The elderly who live with a partner (married) could improve the logodd of a good quality of life 4.94 units higher than the elderly who do not have a partner (not married) $(b=4.94 ; 95 \% \mathrm{CI}=2.49-7.34 ; \mathrm{p}<$ 0.001).

The results of this study are in line with a by Urosevic et al. (2015), Suwarni et al. (2018) and Shrestha et al. (2019) who mentioned that marital status significantly affects quality of life. Someone who is married has a better quality of life than those who are not married, widowed, or widower (Seraji et al, 2017). Gobbens and Remmen (2019) also mentioned that marital status provides a positive correlation with WHOQOL-OLD.

The elderly generally spend more time at home, so the role of the couple is very influential in life, both from physical, psychological, biological, and life satisfaction factors. Couples can provide support functions such as social, emotional, problem sol- ving, financial, and nurturing functions so that quality of life becomes better (Papalia et al., 2009).

\section{The effect of employment status on the quality of life of the elderly}

Employment status had a positive effect on the quality of life of the elderly and was statistically significant. Elderly who is still working actively can improve logodd of good quality of life 6.47 units higher than elderly who do not work $(b=6.47 ; 95 \% \mathrm{CI}=3.18$ 9.76; $\mathrm{p}<0.001)$.

The results of this study are in line with a study conducted by Supraba et al. (2015), Khan and Tahir (2014) and Indrayani and Ronoatmodjo (2018) which stated that work gives significant results on improving the quality of life of the elderly.

Working can improve a person's ability to carry out his role. Elderly who are still working generally have a physical and mental ability and are still able to work. The reason why most of the elderly are still working is because of economic pressure or they have to support their families, children and grandchildren who still live together. Besides, work is a form of self-actualization that affects the 
Fauziyah et al./ Contextual effect of integrated health post, socioeconomic

level of welfare of the elderly. Elderly who do not work tend to be easily anxious, afraid and have economic dependence (Kadarwati et al, 2017).

\section{The effect of income on the quality of life of the elderly}

Income had an effect on the quality of life of the elderly and was statistically significant. Elderly people who had high income can increase the logodd of good quality of life 3.91 units higher than elderly people who had low income $(b=3.91 ; 95 \% \mathrm{CI}=1.45$ to $6.37 ; \mathrm{p}=$ 0.002).

The results of this study are in line with a study conducted by Prasetyaningsih et al. (2016) which stated that income provides significant results on the quality of life of the elderly. A study in India also provides similar results where income is the most important predictor of quality of life (Gupta et al, 2014).

Income plays an important role in the efforts to meet one's needs, including clean and healthy living quarters, a proper and adequate living environment, nutritious food and beverage needs, ease of getting information, availability of transportation, and ease in reaching health services. So that, the quality of life can increase. However, if the necessities of life are not met properly, it will have an impact on the low degree of health which will result in a low quality of life for a person (Azis et al, 2010).

\section{The effect of eating patterns on quality of life}

Eating patterns had a positive effect on the quality of life of the elderly and were statistically significant. Elderly with a good eating pattern (varied) can improve the logodd of a good quality of life 2.08 units higher than the elderly with poor eating pattern (less varied) $(b=2.08 ; 95 \% \mathrm{CI}=0.14$ to $4.02 ; \mathrm{p}=0.036)$. The results of this study are in line with a study conducted by Govindaraju et al (2018) which stated that there is an effect between eating patterns and the quality of life of the elderly. The majority (87\%) of elderly who have a good eating patterns will get a high average quality of life score. Other studies also stated that the higher the quality of food consumed, the better the quality of life (Woo et al., 2010; Milte et al., 2015; ZaragozaMarti et al., 2018).

Elderly who have a good eating pattern will easily achieve a good quality of life, where high quality of life is part of successful aging (Bahrami et al, 2016; Govindaraju et al, 2018).

\section{The effect of physical activity on the quality of life of the elderly}

Physical activity had a positive effect on the quality of life of the elderly and was statistically significant. Elderly with high daily physical activity would increase logodd of good quality of life 3.87 units higher than elderly with low physical activity $(b=3.87$; 95\% CI= 0.80-6.93; $\mathrm{p}=0.013$ ).

The results of this study are in line with a study conducted by Footit and Anderson (2012) which stated that daily physical activity has a positive and significant impact on quality of life. Elderly who are still active in carrying out daily physical activities are proven to consistently increase functional capacity (health of bodily functions) and quality of life (Vagetti et al, 2014). Physical activity in the elderly also helps maintain cardiovascular and cognitive health (Clifford et al, 2014).

Generally, elderly experience a decrease in physical strength which can lead to daily activities and the ability to work has decreased and limited (Lewa, 2016). Low levels of physical activity are associated with an increased risk of mortality and the development of chronic disorders in the elderly (Taylor, 2014). Low physical activity and increased sedentary lifestyle reduce the quality of life score to be lower (Meneguci et al, 2015). 
Fauziyah et al./ Contextual effect of integrated health post, socioeconomic

\section{The effect of nap on the quality of life of the elderly}

Nap had a positive effect on the quality of life of the elderly and were statistically significant. Elderly who had nap habit can increase the logodd of a good quality of life 6.29 units higher than elderly who did not have nap habit $(b=6.29 ; 95 \% \mathrm{CI}=3.05-9.55 ; \mathrm{p}<0.001)$.

The results of this study are in line with a study by Miner and Kryger (2018) which stated that the habit of napping is a positive lifestyle practice for the elderly in improving body health, so that the quality of life becomes better.

Nap provide many benefits for the elderly. Nap provides benefits and potentially provide protection against risk factors for morbidity and mortality for the elderly. Nap can help protect the elderly from the risk of death by shortening the duration of sleep at night (Cohen-Mansfield and Pearch, 2012).

\section{The effect of sexual activity on the quality of life of the elderly}

Sexual activity had a positive effect on the quality of life of the elderly and was statistically significant. Elderly who were still actively engaging in sexual activity with a partner can increase the logodd of a good quality of life 2.97 units higher than the elderly who were no longer actively engaging in sexual activity with their partner $(\mathrm{b}=2.97 ; 95 \% \mathrm{CI}=$ 0.93 to $5.02 ; \mathrm{p}=0.004$ ).

The results are in line with the study of Ropei (2013) which stated that sexual activity affects the quality of life. Sexual activity that is still active in the elderly with their partners can have a positive effect on mental and health conditions (Charoenpoom, 2015).

Sexual activity in elderly couples can strengthen relationships, such as a form of affection, worry between partners, and even able to create happiness. In addition it can provide benefits for physical and psychological well-being, affect the quality of life and mental health, increase heart rate, and reduce the risk of cancer and heart attack (Flynn and Gow, 2015; Pambudi et al, 2018).

8. The effect of activeness in attending integrated health post on the quality of life of the elderly

The activity of joining Integrated Health Post had a positive effect on the quality of life of the elderly and was statistically significant. Elderly who frequently follows elderly integrated health post can improve the logodd of good quality of life 2.18 units higher than elderly who rarely follow elderly integrated health post $(b=2.18 ; 95 \% \mathrm{CI}=0.28$ to 4.09 ; $\mathrm{p}=0.025$ ).

The results of this study are in line with a study conducted by Dewi et al (2017) which stated that elderly who actively participate in participating in various Integrated Health Post activities have a good quality of life.

The activeness of the elderly attending Integrated Health Post is affected by family support, cadre services and health worker services (Anggraini et al., 2015). Family, cadres and health workers support to the elderly to actively participate in Integrated Health Post help the elderly improve their quality of life.

9. The effect of elderly integrated health post on the quality of life

Elderly Integrated Health Post had an Intra Class Correlation (ICC) of $45.65 \%$. This value is an indicator that Elderly Integrated Health Post had a contextual effcer on the quality of life of the elderly which was quite large (ICC $\geq 8-10 \%)$. This means that $45.65 \%$ of the variation in the quality of life of the elderly is determined at the level of the Elderly Integrated Health Post.

According to Baernholdt et al. (2012), utilization of health services is related to quality of life. The establishment of the Elderly Integrated Health Post aims to improve health services for the elderly. The feeling of loneliness and the amount of free time that the elderly have makes the Elderly Integrated 
Fauziyah et al./ Contextual effect of integrated health post, socioeconomic

Health Post as a means of recreation and socializing (Ilyas, 2017). Besides aiming to improve the health of the Elderly Integrated Health Post, it can also support the achievement of welfare for the elderly, so that a good quality of life can be achieved easily.

From the results of this study, it can be concluded that the quality of life of the elderly is affected by marital status, employment status, income, eating patterns, physical activity, nap, sexual activity, and activeness to participate in Integrated Health Post. Variations in the quality of life of the elderly are determined at the level of Elderly Integrated Health Post.

\section{AUTHOR CONTRIBUTION}

Annisa Nur Fauziyah collected and analyzed data. RB. Soemanto tested the framework of the study and conceptual methodology. Rita Benya Adriani tested the results and discussion of the study.

\section{FUNDING AND SPONSORSHIP}

This study used personal funding.

\section{ACKNOWLEDGEMENT}

The author would like to thank Elderly Integrated Health Post who had helped this study and participated as subjects of the study. We also would like to thank elderly integrated health post midwives and cadres who also helped and participated in this study.

\section{REFERENCE}

Anggraini D, Zulpahiyana, Mulyanti (2015). Faktor dominan lansia aktif mengikuti kegiatan posyandu di dusun ngentak. Jurnal Ners dan Kebidanan Indonesia, 3(3): 150-155.

Azis IJ, Lydia MN, Arianto AP, Budy PR (2010). Pembangunan berkelanjutan. Jakarta: Kepustakaan Populer Gramedia.
Baernholdt M, Hinton I, Yan G, Rose K, Mattos $M$ (2012). Factors associated with quality of life in older adults in the United States. Quality of Life Research, 21(3): 527-534. doi: 10.1007/s11136011-9954-z.

Badan Perencanaan Pembangunan Nasional (2013). Proyeksi penduduk Indonesia (Indonesian population projection 2010-2035). Jakarta: Badan Pusat Statistik.

Badan Pusat Statistik (BPS) (2017). Statistik penduduk lanjut usia 2017. Jakarta: Badan Pusat Statistik. 2086-1036.

Bahrami D, Mirzaei M, Abargouei AS (2016). Dietary behaviors of elderly people residing in Central Iran: a preliminary report of Yazd health study. Elder. Health J, Shahid Sadoughi University of Medical Sciences, Yazd, Iran, 2(1): 6-13.

Charoenpoom S (2015). Perceptions of quality well-being among the elderly in the dusit district, Bangkok. Procedia-Social and Behavioral Science, 197: 1570-1574. doi: 10.1016/j.sbspro.2015.07.112.

Clifford A, Rahardjo TB, Bandelow S, Hogervorst E (2014). A cross- sectional study of physical activity and healthrelated quality of life in an elderly Indonesian cohort. Br J Occup, 77(9): 451-456.doi: 10.4276/030802214X14098207541036.

Cohen-Mansfield J, Pearch R (2012). Sleep duration, nap habits, and mortality in older persons. SLEEP: Sleep Research Society, 35(7): 1003-1009. doi: 10.5665/sleep.1970.

Dinas Kesehatan Kabupaten Klaten (2018). Profil lansia kabupaten klaten. (2017). Klaten: Dinas Kesehatan Kabupaten Klaten.

Dinas Kesehatan Provinsi Jawa Tengah (2018). Profil lansia provinsi Jawa Tengah (2017). Semarang: Dinas Kesehatan Provinsi Jawa Tengah. 
Fauziyah et al./ Contextual effect of integrated health post, socioeconomic

Dewi SK, Kusnanto H, Pramantara IDP, Rahayujati TB (2017). Status partisipasi dan kualitas hidup peserta pos pelayanan terpadu lanjut usia. Jurnal Kesehatan Masyarakat, 11(1): 28-40.

Flynn TJ, Gow AJ (2015). Examining associations between sexual behave ours and quality of life in older adults. Oxfrord University Press: Age and Ageing, 44(5): 823-828. doi: 10.1093/ageing/afvo83.

Footit J, Anderson D (2012). Associations between perception of wellness and health-related quality of life, comorbidities, modifiable lifestyle factors and demographics in older Australians. Hous Elderly, 31(1): 7-22.

Gobbens RJJ, Remmen R (2019). The effects of sociodemographic factors on quality of life among people aged 50 years or older are not unequivocal: comparing sf-12, Whoqol-Bref, and Whoqol-old. Dove Medical Press Journal: Clinical Intervention in Aging, 14: 231-239. doi: 10.2147/CIA.S189560.

Govindaraju T, Sahle BW, McCaffrey TA, McNeil JJ, Owen AJ (2018). Dietary patterns and quality of life in older adults: a systematic review. Journal Nutrient, 10: 1-18. doi: 10.3390/nu10080971.

Gupta A, Mohan U, Tiwari SC, Singh SK, Singh VK (2014). Dimensions and determinants of quality of life among senior citizens of Lucknow, India. Int J Med. Public Health, 4(4): 477-481. doi: 10.4103/2230-8598.144122.

Ilyas ANK (2017). Peran posyandu lansia dalam meningkatkan kesejahteraan lanjut usia di posyandu lansia sejahtera kelurahan pasir muncang. E-Plus: Universitas Negeri Semarang, 2(2): 116-213. doi: 10.30870/e-plus.v2i2.2956.

Indrayani, Ronoatmodjo S (2018). Faktorfaktor yang berhubungan dengan kua- litas hidup lansia di desa cipasung kabupaten kuningan tahun 2017. Jurnal Kesehatan Reproduksi, 9(1): 69-78. doi: 10.22435/kespro.v9i1.892.69-78.

Kadarwati, Soemanto RB, Murti B (2017). The nfluence of family support, social capital, self-efficacy, education, employment, income, and residential status on the quality of life among elderly in Salatiga, Central java. J Epidemiol Public Healt, 2(1): 58-69. doi: 10.26911/jepublichealth.2017.02.01.06.

Khan AR, Tahir I (2014). Influence of social factors to the quality of life of the elderly in Malaysia. Open Medicine Journal, 1: 29-35.

Lewa AF (2016). Hubungan pola konsumsi makanan sumber protein, lemak dan aktifitas sedentary dengan status gizi lansia anggota binaan posyandu lansia di kelurahan talise wilayah kerja puskesmas talise. Promotif, 6(2): 8087.

Meneguci J, Sasaki JE, Santos A, Scatena LM, Damiao R (2015). Sitting time and quality of life in older adults: a population-based study. Journal Physical Activity Health, 12(11):1513-1519.doi: 10.1123/jpah.2014-0233.

Milte CM, Thorpe MG, Crawford D, Ball K, McNaughton SA (2015). Associations of diet quality with health-related quality of life in older Australian men and women. Experimental Gerontology, 64: 8-16. doi: 10.1016/j.exger.2015.01.047.

Miner B, Kryger MH (2017). Sleep in the aging population. Sleep Medical Clinic, 12(1): 31-38. doi: 10.1016/j.jsmc. 2016.10 .008 .

Ministry of Health (2010). Profil kesehatan Indonesia tahun 2009. Jakarta: Departemen Kesehatan Republik Indonesia.

Ministry of Health (2014). Infodatin: Situasi lanjut usia (lansia) di indonesia. Jakar- 
Fauziyah et al./ Contextual effect of integrated health post, socioeconomic

ta: Kementerian Kesehatan Republik Indonesia.

Pambudi HA, Dwidiyanti M, Wijayanti DY (2018). Pandangan lansia tentang seksualitas pada lanjut usia. Jurnal Kesehatan, 9(1): 154-159.

Papalia DE, Olds SW, Feldman RD, Gross D (2009). Human development (tenth edition). Boston: McGraw Hill.

Prasetyaningsih RH, Indarto D, Akhyar M (2016). Association of determinant factors on bio-psychosocial with quality of life in elderly. Journal of Epidemiology and Public Health, 1(2): 108-117. doi: 10.26911/jepublichealth.2016.01.02.04.

Ropei, O (2013). Pengalaman responden lanjut usia terhadap perubahan fungsi seksualitas di Kota Cimahi: Studi fenomenologi. Jurnal Keperawatan Soedirman, 8(1): 38-48.

Rusli (2012). Olahraga lanjut usia. Jurnal ILARA, 3(1): 11-19.

Seraji M, Shojaeizadeh D, Goldoost F (2017). Research paper: quality of life the elderly residing in Zahedan (south east of Iran). Iranian Rehabilitation Journal, 15(3): 215-220. doi: 10.29252/nrip.irj.$15 \cdot 3.215$.

Shrestha MCHK, Bhattarai P, Mishra A, Parajuli SB (2019). Quality of life of elderly people living with family and in old age home in Morang district, Nepal. BIBECHANA, 16: 221-227. doi: 10.3126/bibechana.v16io.21643.

Supraba NP, Widarini, NP, Ani LS (2016). The association between social functions and quality of life among elderly in Denpasar. PHPMA, 4(2): 126-129. doi: 10.15562/phpma.v4i2.69.

Suwarni S, Soemanto RB, Sudiyanto A (2018). Effect of dementia, family support, peer support, type of residence, and marital status on quality of life of the elderly in Surakarta, central java. J Epidemiol Public Healt, 3(1): 83-94. doi: 10.26911/jepublichealth.2018.03.01.07 .

Swastika S, Rahardjo SS, Soemanto RB (2017). Bio psychosocial determinants of quality of life in the elderly at Tresna Werdha social nursing home, Yogyakarta. Journal of Epidemiology and Public Health, 2(1): 82-92. doi: 10.26911/jepublichealth.2017.02.01.08.

Taylor D (2014). Physical activity is medicine for older adults. Postgrad Med J, 90(1059): 26-32. doi: 10.1136/postgradmedj-2012-131366.

U.S. News and World Report (2018). Best countries 2018 global rankings, international news and data insights. The Wharton School of the University of Pennsylvania.

Urosevic J, Odovic G, Rapaic D, Davidovic M, Trgovcevic S, Milovanovic V (2015). Quality of life of the elderly in urban and rural areas in Serbia. Vojnosanitetski Pregled, 72(11): 968-974. doi: 10.2298/VSP140831107U.

Woo J, Chan R, Leung J, Wong M (2010). Relative contributions of geographic, socioeconomic, and lifestyle factors to quality of life, frailty, and mortality in elderly. PLoS ONE, 5(1): e8775. doi: 10.1371/journal.pone.0008775.

Vagetti GC, Barbosa Filho VC, Moreira NB, Oliveira V de, Mazzardo O, Campos W de (2014). Association between physical activity and quality of life in the elderly: a systematic review, 2000-2012. Braz J Psychiatry, 36(1): 76-88. doi: 10.1590/1516-4446-2012-0895.

Zaragoza-Marti A, Ferrer-Cascales R, Hurtado-Sanchez JA, Laguna-Perez A, Cabanero-Martinez MJ (2018). Relationship between adherence to the Mediterranean diet and health-related quality of life and life satisfaction among older adults. J Nutr Health Aging, 22(1): 89-96.doi: 10.1007/s12603-017-09 